\title{
HYDROPHOBIZATION OF BASALT FIBER AND ITS INFLUENCE ON THE MECHANICAL CHARACTERISTICS OF SAND CONCRETE
}

\author{
${ }^{1}$ Barabash I.V., D.Sc., Professor, \\ dekansti@ukr.net, ORCID: 0000-0003-0241-4728 \\ ${ }^{1}$ Vorokhaiev A.I., Engineer, \\ voroxaev@gmail.com, ORCID: 0000-0002-4416-7994 \\ ${ }^{1}$ Ksonshkevych L.M., PhD, Assistant Professor, \\ wlksms@gmail.com, ORCID: 0000-0001-9619-4855 \\ ${ }^{1}$ Odessa State Academy of Civil Engineering and Architecture \\ 4, Didrikhson str., Odessa, 65029, Ukraine
}

\begin{abstract}
The materials of the proposed article are devoted to the study of mechanical properties of sand concrete with the addition of hydrophobized basalt fiber and polycarboxylate superplasticizer Relaxol-Super PC. Adding hydrophobic properties to the basalt fiber causes a decrease of water consumption of fine-grained concrete mixture, which leads to improved mechanical properties of concrete.

The aim of the work was to increase the mechanical characteristics of sand concrete by introducing hydrophobized basalt fiber into its composition. The objective of the research is to study the effect of hydrophobized basalt fiber on the mechanical characteristics of sand concrete.

The polycarboxylate superplasticizer Relaxol-Super PC (Budindustriya, Zaporozhye) was used to increase the mobility of the concrete mixture. Basalt fiber Bauson-basalt $12 \mathrm{~mm}$ long and $18 \pm 2 \mu \mathrm{m}$ in diameter was used as a fibrous filler.

Sand concrete mixture was prepared in a laboratory forced-action mixer. Dosing of Portland cement, quartz sand and basalt fiber was carried out by weight, water and water-reducing additive by volume, taking into account the density of the additive. The fiber was introduced into a dry cement-sand mixture. After mixing for $120 \ldots 150$ seconds, water with a dosed amount of additive was introduced into the mixture.

The hardening of samples concrete took place under normal conditions in a chamber with a temperature of $20 \pm 2^{\circ} \mathrm{C}$ and a relative humidity of at least $95 \%$.

The compressive strength of concrete was determined by testing the halves of the samples beams $4 \times 4 \times 16 \mathrm{~cm}$ in size at 28 days of age.

The abrasion of the investigated concrete was determined by testing cube specimens with an edge of $7.07 \mathrm{~cm}$ on an LKI-3 device in accordance with the procedure set forth in DSTU B.V.2.7212: 2009 "Building materials. Concrete. Methods for determining abrasion ".

The impact resistance of concrete was determined from the results of testing cubic specimens with an edge of $7.07 \mathrm{~cm}$ on a vertical dynamic laboratory test machine.

Especially effective is manifested positive role hydrophobization basalt fiber in combination with the water-reducing additive Relaxol-Super PC. The introduction of hydrophobic fiber $\left(2 \mathrm{~kg} / \mathrm{m}^{3}\right)$ and Relaxol - Super PC (1.2\% by weight of cement) into the sand concrete mix provides an increase in the strength of sand concrete by $45 \ldots 48 \%$, impact resistance by $45 \ldots 50 \%$. The abrasion of concrete is reduced by $36 \ldots 48 \%$ compared to the control.
\end{abstract}

Keywords: hydrophobization, basalt fiber, sand concrete, water-reducing additive, abrasion, impact resistance.

Introduction. Among the wide variety of concretes used for flooring industrial and civil buildings, a special place belongs to sand concretes [1].

The use of sandy concrete is especially important for the regions of Ukraine, which are 
experiencing a shortage of high-quality granite crushed stone, and the increasing costs of transporting large aggregate lead to an increase in the cost of concrete.

Possessing a number of positive properties associated with the preparation and placement of concrete mix, sandy concretes are characterized by relatively low compressive strength, reduced impact strength, and increased abrasion. Improving of the operating properties of concrete is achieved by reinforcing it with various types of fibers of organic or mineral origin [2-5].

Analysis of literature data and problem statement. Sandy concrete, due to the presence of a number of positive properties in it, has become widespread in construction. Unlike traditional heavy concrete, sandy concrete lacks a large aggregate, which makes it indispensable for concreting thin-walled structures, the front layer of floors of industrial and civil buildings. Sandy concretes are characterized by increased cement consumption, which causes an increased risk of cracking due to shrinkage deformations [6]. Also, sand concretes are characterized by a relatively low impact resistance, which leads to cracking under impact loading.

By introducing basalt fiber into the sandy concrete mix, the risk of shrinkage cracks is reduced. At the same time, the presence of fiber in the concrete mix increases its water demand, which affects the decrease in the strength of the construction material [7, 8]. A technological method, which consists in hydrophobization of basalt fiber, which leads to a significant decrease in its water absorption is proposed.

Goal and tasks. The aim of the work was to increase the mechanical characteristics of sandy concrete by introducing hydrophobized basalt fiber into its composition. The objective of the study is to determine the effect of hydrophobized basalt fiber on the mechanical characteristics of sandy fiber-reinforced concrete.

Materials and research methods. The studies were carried out using Portland cement of grade 500 PC II / A-Sh-500 produced by Cement LLP (Odessa Cement Plant) with 18\% ground granulated slag content. The specific surface of the cement is $350 \mathrm{~m}^{2} / \mathrm{kg}$. The sand of the Nikitsky quarry (Nikolaevskaya oblast) with $\mathrm{Mk}=2.4$ was used as a fine aggregate.

A polycarboxylate superplasticizer Relaxol - Super PC (Budindustriya, Zaporozhye) was used as a water-reducing additive to the Portland cement. Basalt fiber Bauson-basalt $12 \mathrm{~mm}$ long and $18 \pm 2 \mu \mathrm{m}$ in diameter played the role of a fibrous filler. Fiber hydrophobization was carried out with the use of GKZh-10 organosilicon liquid.

Sandy concrete mixture was prepared in a laboratory forced-action mixer. Dosing of Portland cement, quartz sand and basalt fiber was carried out by weight, water and water-reducing additive by volume, taking into account the density of the additive. The fiber was introduced into a dry cement-sand mixture. After stirring for $120 \ldots 150 \mathrm{~s}$, water with a dosed amount of additive was introduced into the mixture. The hardening of sandy concrete samples took place under normal conditions in a chamber at a temperature of $20 \pm 2^{\circ} \mathrm{C}$ and a relative humidity of at least $95 \%$. The mobility of the sandy concrete mixture was determined by the draft of a standard cone using a device - the StroyTSNIIL cone.

The tensile strength in bending and compression of sandy concrete was determined by testing samples of beams measuring $4 \times 4 \times 16 \mathrm{~cm}$.

The abrasion resistance the concretes under study was determined on cubic samples with an edge of $7.07 \mathrm{~cm}$ using an LKI-3 device in accordance with DSTU BV.2.7-212:2009 "Building materials. Concrete. Methods for determining abrasion".

The impact resistance of sandy concrete was determined according to the results of testing cubic specimens with an edge of $7.07 \mathrm{~cm}$ on a vertical dynamic laboratory test machine. The impact strength of concrete was determined from the expression (1):

$$
\mathrm{T}\left(\mathrm{J} / \mathrm{sm}^{2}\right)=\mathrm{P} \times \sum_{1}^{\mathrm{N}} \mathrm{h} \times \frac{\mathrm{N}}{\mathrm{S}},
$$

where: $\mathrm{P}-$ is the mass of the striker, $\mathrm{kg}$;

$\mathrm{h}-$ is the height of the falling weight, $\mathrm{m}$;

$\mathrm{N}$ - is the number of impacts before the destruction of the sample;

$\mathrm{S}-$ is the area through which the load was transferred, $\mathrm{cm}^{2}$. 
Research results. The study of the strength properties of sand concretes using basalt fiber was carried out according to a 2-factor optimal plan. The following composition factors varied:

$\mathrm{X}_{1}$ - the amount of water-reducing additive Relaxol - Super PC, $0.8 \pm 0.4 \%$ of the cement mass; $X_{2}-$ the amount of basalt fiber, $1 \pm 1 \mathrm{~kg} / \mathrm{m}^{3}$.

The studies were carried out on two similar series of samples using hydrophobized fiber (index "r") and control (index "c"), that is, using untreated fiber. All studied mixtures had the same mobility and amounted to $6 \pm 0.5 \mathrm{~cm}$ by the slump of the cone. Data on the mechanical characteristics of sandy concrete are given in table. 1.

ES-models, built according to those given in Table. 1 data and reflecting the influence of composition factors on the tensile strength of concrete in bending at 3 days of age, have the form:

$$
\begin{aligned}
f_{\text {ctk.3r }}(\mathrm{MPa})=4.4 & +0.6 \mathrm{x}_{1}-0.05 \mathrm{x}_{1}^{2}-0.04 \mathrm{x}_{1} \mathrm{x}_{2} \\
+ & 0.2 \mathrm{x}_{2}-0.1 \mathrm{x}_{2}^{2} \\
f_{\text {ctk.3c }}(\mathrm{MPa})=4.3 & +0.6 \mathrm{x}_{1}-0.08 \mathrm{x}_{1}^{2}-0.03 \mathrm{x}_{1} \mathrm{x}_{2} \\
+ & 0.2 \mathrm{x}_{2}-0.03 \mathrm{x}_{2}^{2}
\end{aligned}
$$

\begin{tabular}{|c|c|c|c|c|c|c|c|c|c|c|}
\hline \multirow[b]{2}{*}{$\begin{array}{c}\text { Ser. } \\
\text { № }\end{array}$} & \multirow[b]{2}{*}{$\mathrm{X}_{1}$} & \multirow[b]{2}{*}{$\mathrm{X}_{2}$} & \multicolumn{2}{|c|}{$f_{\text {ctk. } 3}(\mathrm{MPa})$} & \multicolumn{2}{|c|}{$f_{\text {ctk. }}(\mathrm{MPa})$} & \multicolumn{2}{|c|}{$f_{\text {ck.cube } 3}(\mathrm{MPa})$} & \multicolumn{2}{|c|}{$f_{\text {ck.cube }}(\mathrm{MPa})$} \\
\hline & & & 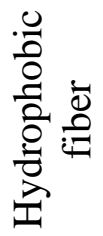 & $\begin{array}{l}\bar{O} \\
\stackrel{\Xi}{0} \\
\text { O }\end{array}$ & 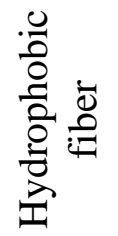 & $\begin{array}{l}\bar{O} \\
\stackrel{\Xi}{0} \\
\text { O }\end{array}$ & 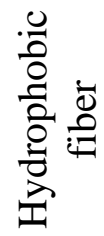 & 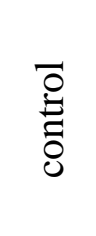 & 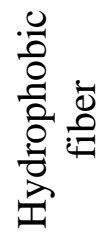 & 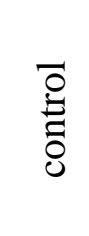 \\
\hline 1 & -1 & -1 & 3.5 & 3.5 & 4.8 & 4.8 & 15.8 & 15.8 & 26.6 & 26.6 \\
\hline 2 & -1 & 0 & 3.8 & 3.7 & 5.4 & 5.1 & 16.9 & 16.6 & 28.6 & 27.8 \\
\hline 3 & -1 & +1 & 4.0 & 3.8 & 5.6 & 5.3 & 17.1 & 16.9 & 29.6 & 29.0 \\
\hline 4 & 0 & -1 & 4.1 & 4.1 & 5.7 & 5.7 & 18.6 & 18.9 & 32.0 & 32.0 \\
\hline 5 & 0 & 0 & 4.4 & 4.3 & 6.2 & 6.0 & 19.8 & 19.4 & 34.3 & 33.2 \\
\hline 6 & 0 & +1 & 4.5 & 4.4 & 6.4 & 6.2 & 20.6 & 20.0 & 35.5 & 34.4 \\
\hline 7 & +1 & -1 & 4.6 & 4.6 & 6.3 & 6.3 & 21.0 & 21.0 & 35.8 & 35.8 \\
\hline 8 & +1 & 0 & 4.9 & 4.8 & 6.7 & 6.5 & 22.2 & 21.8 & 37.5 & 37.0 \\
\hline 9 & +1 & +1 & 5.0 & 4.9 & 6.9 & 6.6 & 22.9 & 22.1 & 38.8 & 38.2 \\
\hline
\end{tabular}

Table 1 - Mechanical characteristics of sand concrete at the age of 3 and 28 days

According to the data of ES models (2) and (3), the maximum values of tensile strength in bending at an early age for concrete with hydrophobized fiber $f_{\text {ctk.3max }}=5.0 \mathrm{MPa}$ and control, respectively $f_{\text {ctk.cmax }}=4.9 \mathrm{MPa}$, is observed at the point with coordinates $\mathrm{x}_{1}=+1$ and $\mathrm{x}_{2}=+1$, that is, with the maximum dosage of water-reducing additive and basalt fiber.

The minimum strength value $f_{\text {ctk. } 3 \mathrm{rmin}}=f_{\text {ctk. } 3 \mathrm{cmin}}=3.5 \mathrm{MPa}$ have the compositions at the point with coordinates $\mathrm{x}_{1}=\mathrm{x}_{2}=-1$, that is, with a minimum amount of water-reducing additive and in the absence of basalt fiber.

ES-models reflecting the effect of the amount of Relaxol - Super PC additive and basalt fiber on the tensile strength of sandy concrete in bending at 28 days of age are as follows:

$$
\begin{aligned}
f_{\text {ctk.r }}(\mathrm{MPa})=6.2 & +0.7 \mathrm{x}_{1}-0.17 \mathrm{x}_{1}^{2}-0.03 \mathrm{x}_{1} \mathrm{x}_{2} \\
+ & 0.35 \mathrm{x}_{2}-0.15 \mathrm{x}_{2}^{2} \\
f_{\text {ctk.c }}(\mathrm{MPa})=6.0 & +0.7 \mathrm{x}_{1}-0.2 \mathrm{x}_{1}^{2}-0.05 \mathrm{x}_{1} \mathrm{x}_{2} \\
+ & 0.2 \mathrm{x}_{2}-0.05 \mathrm{x}_{2}^{2}
\end{aligned}
$$


The fields of properties of ES-models (6) and (7) also show the maximum and minimum values of strength in the same coordinates as for the tensile strength of sandy concrete in bending models (4) and (5).

Analysis of models (6) and (7) allows us to note that the general positive trend from the use of basalt fiber is also preserved for the strength characteristics of concrete under compression. Dispersed-reinforced sand concretes at 3 days of age have $1 \ldots 2 \mathrm{MPa}$ greater strength compared to concrete without fiber and $2 \ldots 3 \mathrm{MPa}$ - at 28 days of age. At the same time, concretes with hydrophobized basalt fibers are characterized by compressive strength $0.5 \ldots 1 \mathrm{MPa}$ more than the strength of concretes with the addition of untreated basalt fiber.

The floors of industrial and public buildings are subject to abrasion during operation, and in some cases to dynamic influences (most often impacts). Accordingly, for concrete floor coverings, the most important properties are wear resistance (abrasion) and impact resistance. Table 2 shows the data on the levels of abrasion and impact resistance of the investigated sand concrete

Table 2 - Abrasion and impact resistance of sand concrete

\begin{tabular}{|c|c|c|c|c|c|c|}
\hline \multirow{2}{*}{$\begin{array}{c}\text { Ser. } \\
\text { № }\end{array}$} & \multirow{2}{*}{$\mathrm{X}_{1}$} & $\mathrm{X}_{2}$ & \multicolumn{2}{|c|}{$\begin{array}{c}\text { Abrasion, } \\
\mathrm{G}_{1}\left(\mathrm{~g} / \mathrm{sm}^{2}\right)\end{array}$} & \multicolumn{2}{c|}{$\begin{array}{c}\text { Impact resistance, } \\
\mathrm{T}\left(\mathrm{J} / \mathrm{sm}^{2}\right)\end{array}$} \\
\cline { 4 - 7 } & & $\begin{array}{c}\text { Hydrophobic } \\
\text { fiber }\end{array}$ & control & $\begin{array}{c}\text { Hydrophobic } \\
\text { fiber }\end{array}$ & control \\
\hline 1 & -1 & -1 & 0.403 & 0.403 & 7.6 & 7.6 \\
\hline 2 & -1 & 0 & 0.329 & 0.342 & 10.8 & 10.7 \\
\hline 3 & -1 & +1 & 0.287 & 0.307 & 12.7 & 12.5 \\
\hline 4 & 0 & -1 & 0.378 & 0.378 & 8.2 & 8.2 \\
\hline 5 & 0 & 0 & 0.304 & 0.310 & 11.4 & 11.2 \\
\hline 6 & 0 & +1 & 0.264 & 0.279 & 13.2 & 12.9 \\
\hline 7 & +1 & -1 & 0.371 & 0.371 & 8.3 & 8.3 \\
\hline 8 & +1 & 0 & 0.288 & 0.309 & 11.6 & 11.5 \\
\hline 9 & +1 & +1 & 0.232 & 0.249 & 13.5 & 13.3 \\
\hline
\end{tabular}

ES-models reflecting the influence of the factors of the composition of sandy concrete at 28 days of age on the level of its abrasion are as follows:

$$
\begin{gathered}
\mathrm{G}_{1 \mathrm{r}}\left(\mathrm{g} / \mathrm{sm}^{2}\right)=0.305-0.021 \mathrm{x}_{1}+0.003 \mathrm{x}_{1}{ }^{2}-0.006 \mathrm{x}_{1} \mathrm{x}_{2} \\
-0.062 \mathrm{x}_{2}+0.016 \mathrm{x}_{2}{ }^{2} \\
\mathrm{G}_{1 \mathrm{c}}\left(\mathrm{g} / \mathrm{sm}^{2}\right)=0.315-0.021 \mathrm{x}_{1}+0.008 \mathrm{x}_{1}{ }^{2}-0.007 \mathrm{x}_{1} \mathrm{x}_{2} \\
-0.053 \mathrm{x}_{2}-0.011 \mathrm{x}_{2}{ }^{2}
\end{gathered}
$$

Analysis of models (8), (9) shows that the highest abrasion resistance $\left(0.232 \mathrm{~g} / \mathrm{cm}^{2}\right)$ is characteristic of the compositions at the point with coordinates $x_{1}=x_{2}=+1$, that is, with the maximum amount of water-reducing additive and hydrophobized basalt fiber. The maximum abrasion $\left(0.403 \mathrm{~g} / \mathrm{cm}^{2}\right)$ of sandy concrete is observed for compositions at the point with coordinates $\mathrm{x}_{1}=\mathrm{x}_{2}=-1$, that is, with a minimum amount of water-reducing additive and without fiber. In general, by increasing the amount of the Relaxol - Super PC additive and introducing hydrophobized basalt fiber, the wear resistance of sandy concrete can be increased by almost $60 \%$, which is the most important effect for the flooring material.

In addition to wear resistance, the resistance of sandy concrete to dynamic loads - impacts was also studied. ES-models reflecting the influence of factors of the composition of sandy concrete on impact resistance are as follows: 


$$
\begin{aligned}
\mathrm{T}_{\mathrm{r}}\left(\mathrm{J} / \mathrm{sm}^{2}\right)=11.39 & +0.38 \mathrm{x}_{1}-0.18 \mathrm{x}_{1}{ }^{2}-0.03 \mathrm{x}_{1} \mathrm{x}_{2} \\
& +2.55 \mathrm{x}_{2}-0.68 \mathrm{x}_{2}{ }^{2} \\
\mathrm{~T}_{\mathrm{c}}\left(\mathrm{J} / \mathrm{sm}^{2}\right)=11.21 & +0.38 \mathrm{x}_{1}-0.12 \mathrm{x}_{1}{ }^{2} \\
+ & 2.43 \mathrm{x}_{2}-0.67 \mathrm{x}_{2}{ }^{2}
\end{aligned}
$$

Analysis of models (10), (11) shows that the maximum impact resistance $\left(13.5 \mathrm{~J} / \mathrm{sm}^{2}\right)$ is shown by the composition at the point with coordinates $\mathrm{x}_{1}=\mathrm{x}_{2}=+1$, that is, with the maximum amount of Relaxol-Super PC additive and hydrophobized basalt fiber. Experimental results of studies of the mechanical properties of sand concrete for floor coverings have shown the effectiveness of the use of hydrophobized basalt fiber in combination with a polycarboxylate additive Relaxol - Super PC.

\section{Conclusions and prospects for further research:}

1. Hydrophobization of the surface of basalt fiber in combination with the superplasticizer Relaxol-Super PK leads to an increase in the tensile strength of concrete in bending (compared to the control) from 4.8 to $6.6 \mathrm{MPa}$. The compressive strength of concrete increases from 26.8 to $38.8 \mathrm{MPa}$, that is, by more than $45 \%$.

2. The analysis of the resistance of the investigated dispersion-reinforced sand concretes to abrasion and dynamic effects has shown the effectiveness of the use of hydrophobized basalt fiber in combination with the additive Relaxol-Super PC. The introduction of basalt fiber in an amount of $2 \mathrm{~kg} / \mathrm{m}^{3}$ reduces the abrasion of sandy concrete by $36 \ldots 48 \%$ compared to the control. The impact resistance of concrete increases by $45 \ldots 50 \%$.

Further research will be aimed at studying the durability of dispersion-reinforced sand concrete.

\section{References}

[1] L.P. Zarubina, Ustroystvo polov. Materialyi i tehnologii. Sankt-Peterburg: «BHVPeterburg», 2011.

[2] A.G. Novitskiy, M.V. Efremov, "Aspektyi primeneniya bazaltovoy fibryi dlya armirovaniya betonov", Stroitelnyie materialyi, izdeliya $i$ sanitarnaya tehnika, vol. 36, pp. 22-26, 2010.

[3] L. Ksonshkevych, I. Barabash, O. Krantovska, S. Synii, P. Sunak, "Disperse reinforced concrete with polycarboxylate additive on a mechanically activated binder", Materials Science and Engineering: IOP Conference Series, no. 708, 2019. 01209. [Online]. Available: https://iopscience.iop.org/ article/10.1088/ 1757-899X/708/1/ 012092. pdf. Accessed on: November 20, 2019.

[4] L. Ksonshkevych, O. Krantovska, M. Petrov, S. Synii and A. Uhl, "Investigation of the structure of cement stone, obtaining and optimization of high-strength concrete on mechanically activated binder", Reliability and Durability of Railway Transport Engineering Structures and Buildings: MATEC Web Conference 230, 03010. [Online]. Available: https://doi.org/10.1051/matecconf/201823003010 pdf. Accessed on: November 20, 2019.

[5] I.V. Barabash, Mehanohimichna aktivaciya mineralnih v'yazhuchih rechovin. Odesa: Astroprint, 2002.

[6] M.O. Kochevykh, Y.I. Smilianets, D.S. Stryhun, "Pidvyshchennia trishchynostiikosti betonnykh elementiv brukuvannia", Naukovi notatky, vol. 43, pp.122-125, 2013.

[7] S.V. Klyuev, Fibrobeton dlya tyazhelonagruzhennyh polov promyshlennyh zdanij. Belgorod: Izd-vo BGTU im. V.G. Shuhova, 2013.

[8] S.V. Klyuev, "K voprosu formirovaniya vyisokokachestvennyih fibrobetonnyih kompozitov", Vestnik Belgorodskogo GTU im.V.G. Shuhova, vol. 6, pp.55-57, 2014. 


\title{
ГІДРОФОБІЗАЦІЯ БАЗАЛЬТОВОЇ ФІБРИ ТА ЇЇ ВПЛИВ НА МЕХАНІЧНІ ХАРАКТЕРИСТИКИ ПНЩАНОГО БЕТОНУ
}

\author{
${ }^{1}$ Барабаш I.B., д.т.н., професор, \\ dekansti@ukr.net, ORCID: 0000-0003-0241-4728 \\ ${ }^{1}$ Ворохаєв A.I., інженер, \\ voroxaev@gmail.com, ORCID: 0000-0002-4416-7994 \\ ${ }^{1}$ Ксьоншкевич Л.М. к.т.н., доцент, \\ wlksms@gmail.com, ORCID: 0000-0001-9619-4855 \\ ${ }^{1}$ Одеська державна академія будівництва та архітектури \\ вул. Дідріхсона, 4, м. Одеса, 65029, Україна
}

Анотація. Матеріали пропонованої статті присвячені дослідженню механічних властивостей піщаного бетону з добавкою гідрофобізованного базальтового волокна i полікарбоксилатного суперпластифікатора Релаксол - Супер ПК. Додання гідрофобних властивостей базальтовому волокну викликає зниження водопотреби дрібнозернистої бетонної суміші, що призводить до поліпшення механічних характеристик бетону.

Метою роботи було підвищення механічних характеристик піщаного бетону за рахунок введення в його склад гідрофобізованного базальтового волокна. Завдання дослідження вивчити вплив гідрофобізованної базальтової фібри на механічні характеристики піщаного фібробетону.

Для підвищення показників бетонної суміші використовувався полікарбоксилатний суперпластифікатор Релаксол - Супер ПК (Будіндустрия, м. Запоріжжя). У якості волокнистого наповнювача використана базальтова фібра Bauson-basalt довжиною 12 мм i діаметром $18 \pm 2$ мкм.

Приготування піщаної бетонної суміші здійснювалося в лабораторному змішувачі примусової дії. Дозування портландцементу, кварцового піску і базальтової фібри виконувалося по масі, вода і водоредукуючі добавки - за обсягом з урахуванням щільності добавки. Фібра вводилася в суху цементопіщану суміш. Після перемішування протягом $120 \ldots 150$ с в суміш вводилася вода з віддозованою кількістю добавки.

Твердіння зразків бетону відбувалося в нормальних умовах в камері при температурі $20 \pm 2{ }^{0} \mathrm{C}$ і відносній вологості повітря не нижче $95 \%$.

Міцність на стиск бетону визначалася шляхом випробування половинок зразків балочок розміром $4 \times 4 \times 16$ см в 28 -ми добовому віці.

Стиранність досліджуваних бетонів визначалася шляхом випробування зразків-кубів 3 ребром 7.07см на приладі ЛКІ-3 відповідно до методики, викладеної в ДСТУ Б.В.2.7 - 212: 2009 «Будівельні матеріали. Бетони. Методи визначення стиранності».

Ударна стійкість бетону визначалася за результатами випробування зразків-кубів 3 ребром 7.07 см на вертикальному динамічному лабораторному копрі.

Особливо ефективно проявляється позитивна роль гідрофобізованної базальтової фібри в поєднанні з водоредукуючою добавкою Релаксол - Супер ПК. Введення до складу піщаної бетонної суміші гідрофобної фібри $\left(2\right.$ кг/м $\left.{ }^{3}\right)$ і добавки Релаксол - Супер ПК $(1.2 \%$ від маси цементу) забезпечує приріст міцності піщаного бетону на 45 ... 48\%, ударної стійкості на 45 ... $50 \%$. Стиранність бетону знижується на $36 \ldots 48 \%$ у порівнянні з контролем.

Ключові слова: гідрофобізація, базальтова фібра, піщаний бетон, водоредукуюча добавка, стиранність, ударна стійкість. 


\title{
ГИДРОФОБИЗАЦИЯ БАЗАЛЬТОВОЙ ФИБРЫ И ЕЕ ВЛИЯНИЕ НА МЕХАНИЧЕСКИЕ ХАРАКТЕРИСТИКИ ПЕСЧАНОГО БЕТОНА
}

\author{
${ }^{1}$ Барабаш И.В., д.т.н., профессор, \\ dekansti@ukr.net, ORCID: 0000-0003-0241-4728 \\ ${ }^{1}$ Ворохаев А.И., инженер, \\ voroxaev@gmail.com, ORCID: 0000-0002-4416-7994 \\ ${ }^{1}$ Ксёншкевич Л.Н. к.Т.н., доцент, \\ wlksms@gmail.com, ORCID: 0000-0001-9619-4855 \\ ${ }^{1}$ Одесская государственная академия строительства и архитектуры \\ ул. Дидрихсона, 4, г. Одесса, 65029, Украина
}

Аннотация. Материалы предлагаемой статьи посвящены исследованию механических свойств песчаного бетона с добавкой гидрофобизированного базальтового волокна и поликарбоксилатного суперпластификатора Релаксол - Супер ПК. Придание гидрофобных свойств базальтовому волокну вызывает снижение водопотребности мелкозернистой бетонной смеси, что приводит к улучшению механических характеристик бетона.

Целью работы было повышение механических характеристик песчаного бетона за счет введения в его состав гидрофобизированного базальтового волокна. Задача исследования изучить влияние гидрофобизированной базальтовой фибры на механические характеристики песчаного фибробетона.

Для повышения показателей бетонной смеси использовался поликарбоксилатный суперпластификатор Релаксол - Супер ПК (Будиндустрия, г. Запорожье). В качестве волокнистого наполнителя использовалась базальтовая фибра Bauson-basalt длиной 12 мм и диаметром $18 \pm 2$ мкм.

Приготовление песчаной бетонной смеси осуществлялось в лабораторном смесителе принудительного действия. Дозировка портландцемента, кварцевого песка и базальтовой фибры выполнялась по массе, вода и водоредуцирующие добавки - по объему с учетом плотности добавки. Фибра вводилась в сухую цементопесчаную смесь. После перемешивания в течение $120 \ldots 150$ с в смесь вводилась вода с отдозированным количеством добавки.

Твердения образцов бетона происходило в нормальных условиях в камере при температуре $20 \pm 2^{0} \mathrm{C}$ и относительной влажностью воздуха не ниже $95 \%$.

Прочность на сжатие бетона определялась путем испытания половинок образцов балочек размером $4 \times 4 \times 16$ см в 28 -ми суточном возрасте.

Истираемость исследуемых бетонов определялась путем испытания образцов-кубов с ребром 7.07см на приборе ЛКИ-3 в соответствии с методикой, изложенной в ДСТУ Б.В.2.7 212: 2009 «Будівельні матеріали. Бетони. Методи визначення стиранності».

Ударная стойкость бетона определялась по результатам испытания образцов-кубов с ребром 7.07 см на вертикальном динамическом лабораторном копре.

Особенно эффективно проявляется положительная роль гидрофобизированной базальтовой фибры в сочетании с водоредуцирующей добавкой Релаксол - Супер ПК. Введение в состав песчаной бетонной смеси гидрофобной фибры $\left(2\right.$ кг/м $\left.{ }^{3}\right)$ и добавки Релаксол Супер ПК (1.2\% от массы цемента) обеспечивает прирост прочности песчаного бетона на $45 \ldots 48 \%$, ударной стойкости на $45 \ldots 50 \%$. Истираемость бетона снижается на $36 \ldots 48 \%$ по сравнению с контролем.

Ключевые слова: гидрофобизация, базальтовая фибра, песчаный бетон, водоредуцирующая добавка, истираемость, ударная стойкость.

Стаття надійшла до редакції 08.10.2020 